\title{
Kemampuan Kelompok Wanita Tani Sri Rejeki dalam Pengolahan Kripik Ketela di Desa Dawan Klod Kecamatan Dawan, Kabupaten Klungkung
}

\author{
NI LUH GEDE MIRAH WISNU PRATIWI, NI WAYAN SRI ASTITI, \\ I GEDE SETIAWAN ADI PUTRA \\ Program Studi Agribisnis, Fakultas Pertanian, Universitas Udayana \\ J1. PB. Sudirman Denpasar 80323 \\ Email: Wisnu_Pratiwi@yahoo.com \\ wayansriastiti@yahoo.com
}

\begin{abstract}
The ability of Women Farmer Group Sri Rejeki in Processing Chips Cassava in the village of Dawan Klod, Dawan Sub-district, Klungkung Regency
\end{abstract}

The objectives of this research are: (1) To know the profile of Sri Rejeki farmer; (2) To know the ability of Women Farmer Group Sri Rejeki in Processing Chips Cassava. This research was conducted at Women Farmer Group Sri Rejeki businessman in Chips Cassava in Dawan Klod Village, Dawan Sub-district, Klungkung Regency taken deliberately. Qualitative and quantitative descriptive data analysis methods. The results showed that, (1) Women Farmer Group Sri Rejeki stood on October 22, 1998, a member of 10 people, chairman Ni Nyoman Simprig. Production capacity of cassava chips per day $1,500 \mathrm{pcs}$ and in order to increase to 2,500 pcs or more; (2) The ability of Women Farmer Group Sri Rejeki in processing Chips Cassava including medium category with score 3,20. From the results of this study can be suggested: (1) Farmers group of women as Community Direct Assistance fund users need to improve the performance and quality of its processed products, so as to increase the selling value and income of groups and individuals; (2) Community Direct Assistance program for the domestic industry should be developed not only within the city but also in the countryside, thus it is expected that farmers' production can be absorbed as raw material for processed products.

Keywords: processing chips cassava, women farmer group, ability

\section{Pendahuluan}

\subsection{Latar Belakang}

Pembangunan pertanian di Indonesia masih menjadi sektor terpenting dari keseluruhan pembangunan ekonomi. Sejak dahulukala masyarakat Indonesia khususnya di pedesaan telah terpolakan kehidupannya sebagai masyarakat agraris, pengembangan sektor pertanian, stabilitas ekonomi nasional dapat terjamin. Pembangunan pertanian merupakan bagian integral dari pembangunan ekonomi yang dijadikan sektor andalan dari perekonomian nasional. Tertuang dalam Rencana Strategis Dinas Pertanian, Perkebunan dan Kehutanan Kabupaten Klungkung tahun 2013 sampai dengan 2018. Visi pembangunan pertanian saat ini adalah 
"Terwujudnya masyarakat sejahtera melalui pembangunan sistem dan usaha agribisnis yang berdaya saing, berkerakyatan, dan berkelanjutan yang berlandaskan Tri Hita Karana" (Dinas Pertanian, Perkebunan dan Kehutanan Kabupaten Klungkung, tahun 2014).

Pembangunan ekonomi nasional berbasis pertanian dan perdesaan secara langsung akan berdampak pada pengurangan penduduk miskin. Permasalahan mendasar yang dihadapi petani adalah kurangnya akses pada sumber permodalan, pasar dan teknologi serta organisasi petani yang masih lemah (Sunanjaya dan Sumawa, 2009). Kehidupan agraris juga masih terlihat di Bali sekalipun adanya pergeseran orientasi profesi dari sektor pertanian kearah sektor jasa (pariwisata). Diketahui bahwa dalam menjalankan pembangunan pertanian tidak terlepas dari beberapa faktor yang merupakan modal pembangunan pertanian seperti lahan, air, sarana dan prasarana, sumberdaya manusia, Iptek dan permodalan. Suparta (2005) mengatakan bahwa sumberdaya manusia adalah modal utama pembangunan, tanpa SDM yang memadai maka laju pertumbuhan ekonomi tidak akan bisa sebagaimana yang diharapkan.

Perempuan sebagai bagian dari masyarakat Indonesia perlu diperhitungkan keikutsertaannya sebagai sumberdaya pembangunan, sebagaimana tertuang dalam undang-undang No. 25/2000 tentang Program Pembangunan Nasional, telah memasukan program-program pemberdayaan perempuan. Situasi ini lebih nampak di pedesaan, karena sejak kecil mereka telah dididik oleh orang tua mereka untuk dapat melakukan segala pekerjaan baik pekerjaan rumah tangga maupun pekerjaan lain di luar rumah tangga untuk mendukung keluarga. Keadaan ini juga tampak di Bali, dimana wanita Bali umumnya pekerja keras dan tekun, sebagaimana diungkapkan Astiti (2006), bahwa perempuan Bali selain aktif dalam kegiatan rumah tangga, perempuan pedesaan juga berperan dalam kegitan usahatani.

Umumnya usaha pertanian yang dilakukan oleh perempuan masih bersifat usaha keluarga yang masih memiliki keterbatasan modal. Sejak tahun 1999 sampai dengan 2013 sudah terbentuk Kelompok Wanita Tani sejumlah 225 kelompok yang tersebar di Sembilan Kabupaten Kota se Bali sebagai wadah bagi para wanita tani untuk mengembangkan usahataninya agar lebih diperhatikan oleh pemerintah (Dinas Pertanian Tanaman Pangan Provinsi Bali, 2013). Sampai dengan tahun 2013 telah terbentuk 39 kelompok wanita tani yang menyebar di Kabupaten Klungkung (Dinas Pertanian, Perkebunan dan Kehutanan Kabupaten Klungkung, 2013).

Wanita Bali di pedesaan sebenarnya memiliki potensi untuk diberdayakan melalui sektor pertanian, walaupun bagi usaha pertanian rakyat yang mereka miliki masih menghadapi kendala permodalan. Anoraga (2004) menyatakan bahwa ada beberapa alternatif yang dapat dilakukan untuk mendapatkan pembiayaan sebagai modal dasar untuk langkah-langkah pengembangan usaha agribisnis. Alternatif tersebut yaitu melalui kredit perbankan KKP, pinjaman lembaga keuangan bukan bank, modal ventura, pinjaman dari dana penyisihan sebagai laba BUMN, dan pembiayaan lainnya. Pernyataan tersebut didukung oleh Astiti (2006), bahwa wanita 
tani kurang mendapatkan kesempatan untuk memperoleh akses terhadap sumbersumber informasi, karena meraka sangat jarang diikutkan dalam kegiatan pendidikan, penyuluhan ataupun pelatihan di sektor pertanian.

Bantuan langsung masyarakat (BLM) adalah pemberian bantuan sejumlah dana untuk penguatan modal kelompok yang disalurkan langsung ke rekening kelompok dan dikelola secara terorganisir dengan azas kebersamaan untuk usaha produktif dengan mekanisme pemupukan modal (bukan bantuan cuma-cuma). Bantuan modal pada kelompok usaha dimaksudkan untuk pengadaan alat-alat yang akan dibutuhkan dan juga dialokasi anggaran dalam menjalankan usaha harus dibicarakan secara musyawarah dan kesepakatan bersama yang disetujui oleh kelompok (Dinas Pertanian Tanaman Pangan Provinsi Bali, 2013).

Kinerja berasal dari kata job performance atau actual performance yang berarti prestasi kerja atau prestasi sesungguhnya yang dicapai oleh seseorang. Pengertian kinerja (prestasi kerja) adalah hasil kerja secara kualitas dan kuantitas yang dicapai oleh seorang pegawai dalam melaksanakan fungsinya sesuai dengan tanggung jawab yang diberikan kepadanya. Performance atau kinerja merupakan hasil atau keluaran dari suatu proses (Nurlaila, 2010). Menurut pendekatan perilaku dalam manajemen, kinerja adalah kuantitas atau kualitas sesuatu yang dihasilkan atau jasa yang diberikan oleh seseorang yang melakukan pekerjaan (Luthans, 2005). Rivai (2005) menyebutkan bahwa kinerja adalah kesediaan seseorang atau kelompok orang untuk melakukan sesuatu kegiatan dan menyempurnakannya sesuai dengan tanggung jawabnya dengan hasil seperti yang diharapkan. Kinerja adalah hasil kerja baik secara kualitas maupun kuantitas yang dicapai oleh seseorang dalam melaksanakan tugas sesuai tanggung jawab yang diberikan (Mangkunagara, 2002).

\subsection{Tujuan}

Tujuan yang ingin dicapai dalam penelitian ini adalah untuk mengetahui profil wanita tani Sri Rejeki dan kemampuan kelompok wanita tani Sri Rejeki dalam pengolahan kripik Ketela.

\section{Metode Penelitian}

\subsection{Lokasi dan Waktu Penelitian}

Penelitian ini dilakukan di Kelompok Wanita Tani Sri Rejeki yang berlokasi di Desa Dawan Klod, Kecamatan Dawan, Kabupaten Klungkung, Bali, pada bulan Juli - Oktober 2016. Pemilihan lokasi ini dilakukan dengan metode purposive (sengaja), yaitu pemilihan lokasi secara disengaja berdasarkan atas pertimbangan-pertimbangan tertentu.

\subsection{Jenis dan Sumber Data}

Data yang dikumpulkan dalam penelitian ini adalah data kualitatif dan data kuantitatif. Data kualitatif yaitu data yang tidak dapat dihitung dengan satuan hitung atau tidak berupa angka melainkan keterangan yang berhubungan dengan masalah 
yang diteliti. Data kuantitatif yaitu data dalam bentuk angka-angka atau data-data yang dapat dihitung dan dinyatakan dalam bentuk satuan hitung. Sumber data terdiri atas data primer dan data skunder. Data primer, merupakan data yang langsung dari sumbernya. Pengumpulan data primer dalam penelitian ini melalui observasi dan wawancara dengan menggunakan kuisioner yang disebar kepada responden KWT. Data sekunder, merupakan sumber data yang sudah tersedia. Sumber data sekunder dalam penelitian ini meliputi, literatur, artikel, jurnal, situs di internet, gambaran umum daerah penelitian yang berkaitan dengan penelitian yang dilakukan.

\subsection{Metode Pengumpulan Data}

Metode pengumpulan data yang digunakan dalam penelitian ini meliputi wawancara, observasi, dokumentasi dan studi kepustakaan. Metode wawancara terdiri dari wawancara terstruktur dan wawancara mendalam. Wawancara terstruktur merupakan wawancara yang dilakukan dengan pedoman wawancara dengan menggunakan alat dalam bentuk kuisioner dengan cara menyebar daftar pertanyaan kepada responden yang dijadikan sampel penelitian. Wawancara mendalam (Indepth interview ) adalah merupakan proses mencari informasi yang dilakukan dengan tatap muka antara pewawancara dengan responden atau narasumber, dengan instrument penelitian, yaitu pedoman wawancara. Indepth interview merupakan proses memperoleh keterangan untuk tujuan penelitian dengan cara tanya jawab dan bertatap muka, dimana informan terlibat dalam kehidupan social yang relatif lama (Sutopo, 2006). Observasi merupakan suatu proses yang kompleks, suatu proses yang tersusun dari berbagai proses biologis dan psikologis. Dokumentasi merupakan pemberian atau mengumpulkan bukti atau keterangan, yang dapat berupa kutipan surat kabar, dan gambar (Poerwadarminta, 2007 dalam Kamus Umum Bahasa Indonesia). Studi kepustakaan yaitu pengumpulan data yang dilakukan dengan mengkaji dokumen baik berupa referensi dan foto-foto yang berhubungan dengan penelitian ini.

\subsection{Populasi, Responden, dan Informan Kunci}

Populasi dari penelitian ini yaitu seluruh anggota KWT Sri Rejeki yang berjumlah 10 orang. Seluruh anggota KWT dijadikan sampel penelitian dengan menggunakan teknik sensus, sehingga responden berjumlah 10 orang. Informan kunci pada penelitian ini mencakup ketua kelompok wanita tani dan PPL sebagai pendamping.

\subsection{Konsep Variabel, Indikator, Parameter, dan Skala Pengukuran}

Variabel yang digunakan dalam penelitian ini adalah (1) Kemampuan merencanakan sebagai pedoman dalam pelaksanaan kegiatan untuk memproduksi kripik ketela kedepannya dari penyediaan bahan baku, penyediaan alat-alat produksi dan pemasarannya, (2) Kemampuan melaksanakan keberlanjutan produksi, (3) Kemampuan memupuk modal melalui iuran kelompok, bantuan BLM, peningkatan kualitas produksi dan kuantitas produksi, (4) Kemampuan meningkatkan hubungan 
kerjasama antar anggota kelompok sehingga dapat nenciptakan suasana yang harmonis, dan (5) Kemampuan menerapkan teknologi dan memanfaatkan informasi melalui media komunikasi dan sumberdaya yang ada. Metode analisis data yang digunakan dalam penelitian ini adalah metode analisis deskriptif kualitatif dan kuantitatif. Konsep yang diukur pada penelitian ini adalah kemampuan kelompok wanita tani, yang terdiri dari 12 parameter dan sembilan indikator dengan menggunakan metode kualitatif dan skoring.

\section{Hasil dan Pembahasan}

\subsection{Karakteristik Responden}

Karakteristik responden dalam penelitian ini meliputi: a) status perkawinan, b) umur/usia responden, c) tingkat pendidikan formal terakhir, dan d) jenis pekerjaan.

\subsubsection{Status perkawinan}

Pengertian perkawinan menurut Undang-undang No. I tahun 1974 adalah ikatan lahir batin antara seorang pria dan seorang wanita sebagai suami-istri dengan tujuan membentuk keluarga (rumah tangga) yang bahagia dan kekal berdasarkan Ketuhanan Yang Maha Esa. Berdasarkan hasil penelitian yang telah dilakukan di kelompok wanita tani Sri Rejeki seluruh responden dalam penelitian ini berstatus sudah menikah.

\subsubsection{Umur}

Hasil penelitian menunjukkan bahwa, rata-rata umur responden adalah 46 tahun yang terdapat pada kisaran kelompok umur 37 tahun sampai 55 tahun. Sebanyak 10 orang Wanita Tani termasuk dalam kategori produktif. Jadi seluruh anggota KWT berada pada kategori produktif, ini berarti responden memiliki kemampuan untuk bekerja sehingga dapat memanfaatkan BLM dengan baik untuk memproduksi kripik ketela.

\subsubsection{Tingkat pendidikan formal}

Tingkat pendidikan formal yang ditempuh oleh anggota KWT Sri Rejeki pendidikannya kebanyakan SMA, dengan pendidikan ini sudah cukup untuk mengolah kripik ketela.

\subsubsection{Pekerjaan}

Berdasarkan hasil penelitian ini bahwa status pekerjaan pokok responden kelompok wanita tani Sri Rejeki sebagian besar (90\%) bekerja sebagai produsen kripik yaitu berjumlah sembilan orang, dan satu orang responden sebagai pedagang (10\%). Jadi dapat dikatakan sebagian besar responden memiliki pekerjaan pokok sebagai produsen kripik, ini berarti responden lebih fokus atau mencurahkan waktu lebih banyak untuk memproduksi kripik ketela di KWT Sri Rejeki. 


\subsubsection{Anggota rumah tangga}

Jumlah anggota rumah tangga responden termasuk kategori sedikit adalah terdapat pada tujuh rumah tangga dengan jumlah anggota masing-masing empat orang sehingga jumlah pertanggungannya menjadi 28 orang, pada anggota rumah tangga responden termasuk kategori sedang terdapat pada dua rumah tangga dengan jumlah anggota masing-masing lima orang sehingga jumlah pertanggungannya menjadi 10 orang dan jumlah anggota rumah tangga responden termasuk kategori banyak terdapat pada satu rumah tangga dengan anggota enam orang sehingga jumlah pertanggungannya menjadi enam orang. Hal ini menunjukkan bahwa anggota KWT Sri Rejeki dari 10 responden $70 \%$ memiliki banyak waktu untuk menjalankan usaha pengolahan kripik ketela.

\subsection{Profil Kelompok Wanita Tani Sri Rejeki}

\subsubsection{Sejarah Kelompok Wanita Tani Sri Rejeki}

Sejarah singkat berdiri KWT Sri Rejeki dijelaskan bahwa pada awalnya ibu Ni Nyoman Simprig mengolah hasil pertanian berupa ketela menjadi kripik ketela yang dijual diwarung-warung di Desa Dawan Klod. Kelompok wanita tani Sri Rejeki berdiri pada tanggal 22 Oktober 1998 dengan anggota sebanyak 7 orang dan pada tahun 2009 jumlah anggota meningkat menjadi 10 orang. Pada tanggal 6 Mei 2004 ibu Ni Nyoman Simprig selaku ketua KWT Sri Rejeki mengikuti pelatihan bimbingan teknis food safety star award yang diselenggarakan oleh Balai Besar Pengawas Obat dan Makanan di Denpasar. Melihat usaha industri rumah tangga yang digeluti oleh KWT Sri Rejeki memiliki prospek yang bagus, maka pada tahun 2013 Dinas Pertanian Kabupaten Klungkung memberikan dana BLM-UP3HP kepada KWT dengan jumlah anggota 10 orang.

\subsubsection{Tujuan Kelompok Wanita Tani Sri Rejeki}

Tujuan dibentuknya KWT Sri Rejeki adalah untuk memajukan industri rumah tangga yang ada di Desa Dawan Klod dan memberikan lapangan pekerjaan bagi ibu rumah tangga agar dapat membantu ekonomi keluarga.

\subsubsection{Jenis Usaha dan Produksinya}

Jenis usaha yang dijalankan adalah jenis usaha industri rumah tangga yang dirintis KWT dan masih berskala kecil. KWT hanya memperkerjakan anggota kelompoknya untuk memproduksi kripik ketela dan kue gabin. kapasitas produksi per hari yang dicapai KWT Sri Rejeki sebanyak 1.500 pcs untuk kripik ketela dan 500 kotak untuk kue gabin.

\subsubsection{Struktur Oragnisasi KWT Sri Rejeki}

Struktur Organisasi Kelompok Wanita Tani Sri Rejeki adalah Ketua: Ni Nyoman Simprig, Bendahara: Ni Wayan Ekawati, Sekretaris: Ni Made Arti, 
Anggota: Ni Komang Sindriya, Ni Ketut Sulasih, Ni Nengah Murtini, Ni Komang Rupini, Ni Ketut Arini, Ni Wayan Silawati, dan Ni Komang Gumanti.

\subsection{Kemampuan kelompok wanita tani dalam pengolahan krpik ketela}

Penelitian ini mengkaji tentang kemampuan kelompok wanita tani Sri Rejeki. Untuk mengetahui kemampuan kelompok wanita tani tersebut digunakan beberapa indikator yaitu, kemampuan merencanakan, kemampuan melaksanakan, kemampuan memupuk modal, kemampuan meningkatkan hubungan, kemampuan menerapkan teknologi, dan memanfaatkan informasi.

\subsubsection{Kemampuan merencanakan}

Kemampuan kelompok tani dilihat dari indikator kemampuan merencanakan dengan parameter kemampuan berproduksi termasuk kategori sedang dengan pencapaian skor yaitu 3,10, karena KWT Sri Rejeki belum mempunyai perencanaan secara rinci sebagai pedoman dalam pelaksanaan kegiatan memproduksi kripik ketela. KWT agar menyusun perencanaan mulai dari penyediaan bahan baku, penyediaan alat-alat produksi dan pemasarannya sehingga kelompok dalam memproduksi kripik ketela per harinya bisa meningkat dari 1.500 pcs menjadi 2.500 pcs atau lebih. Bahan baku kripik ketela dapat dipasok dari desa lain sehingga produksi kripik tetap berjalan lancar, penyediaan alat-alat produksi agar tidak menghambat proses produksi, dan pemasaran kripik ketela yang diproduksi oleh KWT Sri Rejeki dapat bersaing di pasaran sehingga bisa memenuhi permintaan pasar dengan berproduksi secara berkelanjutan.

\subsubsection{Kemampuan melaksanakan}

Kemampuan kelompok wanita tani dilihat dari indikator kemampuan melaksanakan dengan parameter keberlanjutan berproduksi termasuk kategori sedang dengan pencapaian skor yaitu 3,30, karena dalam memproduksi kripik ketela KWT Sri Rejeki baru melayani pesanan, diharapkan nantinya agar bisa berproduksi secara berkelanjutan dan dapat memenuhi permintaan pasar sampai ke swalayan dan tokotoko. Keberlanjutan produksi kripik ketela ketua dan anggota KWT bersama-sama mempunyai inisiatif untuk meningkatkan produksinya. KWT Sri Rejeki mendapat pembinaan-pembinaan dari PPL, Dinas Pertanian Kabupaten Klungkung, dan instansi terkait sehingga dengan cepat dapat mengadopsi teknologi baru untuk meningkatkan pengetahuan dan ketrampilan kelompok wanita tani dalam usaha industri rumah tangga.

\subsubsection{Kemampuan memupuk modal}

Kemampuan kelompok wanita tani dilihat dari indikator kemampuan memupuk modal dengan parameter kualitas dan kuantitas produksi kripik ketela termasuk kategori sedang dengan pencapaian skor yaitu 3,10. Hal yang perlu ditingkatkan adalah permodalan kelompok wanita tani awalnya memiliki modal sebesar Rp. 2.100.000,00 yang bersumber dari iuran anggota kelompok dan pada tahun 2013 mendapat bantuan dana dari BLM-UP3HP sebesar Rp. 22.000.000,00 
sehingga perkembangan usaha kelompok semakin berkembang. Modal yang diterima sampai saat ini telah dikembalikan ke kelompok UP3HP Kabupaten Klungkung sebesar Rp. 23.584.000,00 (termasuk modal dan bunga) dan sisanya sebesar Rp.6.336.000,00. Besarnya bunga pinjaman per tahun adalah 12\%, bunga tersebut dikembalikan ke kelompok UP3HP 20\% dan 80\% untuk pemupukan modal kelompok. Sisa modal sebesar Rp. 6.336.000,00 yang digunakan sampai saat ini berkembang menjadi Rp. 10.112.000,00. Kinerja KWT Sri Rejeki dilihat dari segi kuantitas produksi kripik ketela termasuk kategori sedang, karena produksi per hari kurang lebih 1.500 pcs. KWT Sri Rejeki telah menjalin kerja sama dengan petani setempat maupun dengan petani di luar desa sebagai penyedia bahan baku, kemudian pemasarannya bekerja sama dengan pengusaha yang lebih besar. Semakin berkembangnya usaha dalam artian volume usaha semakin besar maka kelompok memperluas pemasaran baik di Kabupaten Klungkung maupun di luar kabupaten. Hasil dari penjualan produksi disimpan dijadikan modal kembali, agar kas dalam kelompok dapat terus bertambah. Kualitas produksi termasuk kategori sedang, dilihat dari segi proses pembuatan kripik KWT belum trampil, dari segi rasa masih kurang, variasinya masih kurang dan pengemasannya masih manual sehingga perlu adanya pembinaan-pembinaan dari instansi terkait.

\subsubsection{Kemampuan meningkatkan hubungan}

Kemampuan kelompok wanita tani dilihat dari indikator kemampuan meningkatkan hubungan dengan parameter suasana kelompok dan kerjasama termasuk kategori sedang dengan pencapaian skor yaitu 3,30, KWT harus lebih menjaga kebersamaan dan keakraban kelompok agar bisa terjalin hubungan dengan sesama anggota kelompok. Salah satu cara menjaga agar suatu kelompok tetap kompak dan bertahan adalah dengan melakukan interaksi dengan sesama anggota kelompok sehingga dapat tercipta rasa memiliki dan adanya rasa kekeluargaan dalam diri masing-masing. Rapat rutin merupakan salah satu bentuk interaksi tatap muka sederhana kelompok dalam menjaga kekompakan suatu kelompok. Melalui rapat kelompok tersebut akan terjadi suatu proses komunikasi yaitu pertukaran pendapat, saling berbagi pengalaman, informasi sehingga dapat meningkatkan pengetahuan anggota.

\subsubsection{Kemampuan menerapkan teknologi dan memanfaatkan informasi}

Kemampuan kelompok wanita tani dilihat dari indikator kemampuan menerapkan teknologi dan memanfaatkan informasi termasuk kategori sedang dengan pencapaian skor yaitu 3,20, karena KWT Sri Rejeki kurang mendapat kesempatan untuk memperoleh akses terhadap sumber-sumber informasi, dan jarang diikutkan dalam kegiatan pendidikan, penyuluhan atau pelatihan di sektor pertanian maupun mengikuti diklat-diklat yang lain. Dilihat dari parameter penggunaan sumberdaya termasuk kategori sedang dengan pencapaian skor 3,30. KWT memanfaatkan sumberdaya alam yang ada seperti bahan baku yang diperoleh dari 
petani di Desa Dawan Klod dan sekitarnya, tetapi pada saat tertentu KWT kekurangan bahan baku untuk memproduksi kripik karena bahan baku yang digunakan bersifat musiman dan tidak bisa disimpan terlalu lama, dan juga sumber daya manusianya pada KWT Sri Rejeki dalam memproduksi kripik ketela belum trampil. Dilihat dari parameter media yang digunakan termasuk kategori sedang dengan pencapaian skor 3,10. KWT memanfaatkan media komunikasi dalam pemasaran produksi kripik ketela masih kurang, kedepannya agar mampu menggunakan media alat bantu komunikasi (sosial media) sebagai alat untuk memasarkan produknya kepada konsumen.

\section{Simpulan dan Saran}

\subsection{Simpulan}

Kemampuan kelompok wanita tani Sri Rejeki dalam pengolahan kripik ketela termasuk kategori sedang dengan pencapaian skor rata-rata 3,20. Kategori sedang ini dilihat dari indikator kemampuan : merencanakan, melaksanakan, memupuk modal, meningkatkan hubungan, menerapkan teknologi, dan memanfaatkan informasi.

\subsection{Saran}

Kelompok wanita tani sebagai pengguna dana bantuan langsung masyarakat (BLM) perlu meningkatkan kinerja dan kualitas produk olahannya, sehingga dapat meningkatkan nilai jual dan pendapatan kelompok maupun perorangan. Program Bantuan Langsung Masyarakat bagi pelaku usaha industri rumah tangga perlu dikembangkan tidak didalam kota saja tetapi juga dipedesaan, dengan demikian diharapkan produksi petani bisa diserap sebagai bahan baku produk olahan.

\section{Ucapan Terimakasih}

Terimakasih kepada seluruh pihak yang telah memberikan pengarahan, bimbingan dan juga dukungan dalam penyelesaian penelitian dan penulisan e-jurnal ini. Semoga penelitian ini dapat bermanfaat sebagaimana mestinya.

\section{Daftar Pustaka}

Anaroga, Panji. 2004. Modal Pembiayaan Manajemen Bisnis. Kerjasama Sekolah Tinggi Ilmu Ekonomi (STIE). Rineka Cipta : Yogyakarta.

Astiti, N.W.Sri. 2006. Curahan Tenaga Kerja Perempuan pada Usahatan Padi di Subak Guama Kabupaten Tabanan dalam Kembang Rampai Perempuan Bali. Hal. 85. Diedit oleh Luh Aryani, Nyoman Suparwa dan Sudarta. Kerjasama Biro BKPP Setda Bali dan Pusat Studi Wanita UNUD, Denpasar.

Dinas Pertanian, Perkebunan, dan Kehutanan Kabupaten Klungkung. 2014. Rencana Strategis.

Dinas Pertanian Tanaman Pangan Provinsi Bali. 2013. Petunjuk Teknis Unit Pelayanan Pengembangan Pengolahan Hasil Pertanian (UP3HP).

Luthans, Fred, 2005. Prilaku Organisasi, Edisi Sepuluh, Diterjemahkan oleh :Vivin Andhika Yuwono; Shekar Purwanti; Th.Arie Prabawati; dan Winong Rosari. Penerbit Andi : Yogyakarta 
Mangkunegara, Anwar Prabu . 2002. Manajemen Sumber Daya Manusia. Remaja Rosdakarya. Bandung

Nurlaila, 2010. Manajemen Sumber Daya Manusia I. Ternate: Penerbit Lep Khair

Sunanjaya, W, Sumawa, N. 2009. Identifikasi dan Peluang Pengembangan Potensi Desa. Apresiasi Inovasi Teknologi Pertanian Mendukung PUAP 2009. Balai Pengkajian Teknologi Pertanian Bali. Denpasar.

Suparta, Nym. 2005. Pendekatan Holistik Pembangunan Agribisnis. Cetakan ke 1, Editor: Jiwa Atmaja. CV. Bali Media Adhikarsa. Denpasar.

Veithzal Rivai (2005). Manajemen Sumber Daya Manusia untuk Perusahaan. Penerbit PT. Raja Grafindo Persada : Jakarta 